\title{
Farewell to a Great Gestalt Psychologist Anna Arfelli Galli 1933-2019
}

Anna Arfelli Galli passed away on May 1 this year. With her death, the international scientific community loses an uncommonly committed, versatile, and open-minded personality in research and teaching in developmental psychology and educational psychology. With her death, the Society for Gestalt Theory and its Applications lose a lovable colleague and supporter, one of its honorary members, one of the most important representatives of Gestalt theory in Italy.

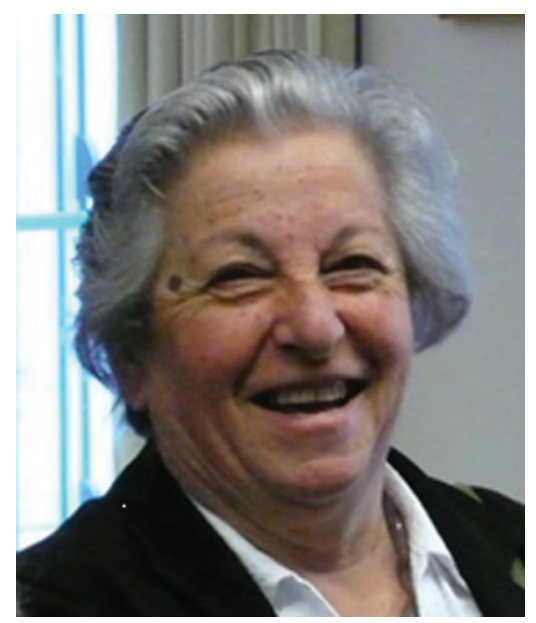

Anna Arfelli was born in Ravenna on September $9^{\text {th }}$, 1933. During her school years, she had already got to know and love Giuseppe Galli, with whom she should be connected in a lifelong partnership in personal and scientific life. In 1957, she earned her doctorate summa cum laude in Medicine and Surgery at the University of Bologna. Her dissertation was already dedicated to a developmental psychological topic, "The reaction of the infant's smiling." The supervisor of this dissertation was Professor Renzo Canestrari, known as the founder of the Bologna School of Gestalt Psychology, who familiarized her (as well as her husband Giuseppe Galli and others) with Gestalt psychology.

In 1960, she completed her specialist training in Medicine in what were then known as "nervous and mental diseases" with a dissertation on behavioral disorders in adolescence. This was followed by several years of intensive clinical and 
research work under the guidance of Canestrari. Her Gestalt psychology education also deepened during these years, supported by encounters with some of the most renowned Gestalt psychologists of the time from other countries brought to Bologna by Canestrari - including Wolfgang Metzger, Edwin Rausch, Wilhelm Witte, and Rudolf Arnheim. Anna Arfelli Galli also trained in group analysis with the German-Italian physician Alice Ricciardi von Platen, one of the first group analysts in Italy, and with the psychoanalysts Augusto Ricciardi and Giampaolo Lai in the 1960s.

From the very beginning, Anna Arfelli's ' professional life was characterized by her striving to combine her work in research and science with her practical commitment to improving people's living conditions. In Bologna, for example, she, along with Augusto Palmonari, Professor of Social Psychology and Psychiatry, set up a house for adolescents with serious psychosocial difficulties. Thus, for the first time, an alternative to the common practice in Italy (as in other countries) of locking away and forcibly disciplining so-called difficult children and adolescents in closed institutions and similar "total institutions" arose. A few years later, in the small community of Montelparo, she set up the medical-psychological-pedagogical institute "G. Mancinello" — organized according to the principle of the family groups and put at the service of the local community - again an innovative institution.

These reform initiatives contributed directly to the improvement of the living conditions of the people concerned and to a new way of thinking of the people in their social environment. At the same time, they gave Anna Arfelli Galli an opportunity to review in practice the results of her theoretical studies on developmental age and disorders in childhood and adolescence. The influence of Kurt Lewin's approach to action research can easily be recognized in these initiatives.

In 1970, Anna Arfelli Galli was appointed Lecturer in Developmental Psychology. Since 1971, she taught Developmental Psychology at the University of Macerata, where she became an Associate Professor from 1982 and a Full Professor from 1991 (Professor of School Psychology till 2003). During her research and teaching activities, Arfelli maintained her advisory work for families and minors in difficulty, employing her double qualification as a neuropsychiatrist and psychologist.

From the 1980s onwards, Anna Arfelli took an active part in the debates on the reform of university didactics, which, at the time, was still marked by the generally predominant frontal lectures, and was committed to the promotion of alternative, participatory teaching methods with a workshop character, which she also practiced in her own courses. These efforts eventually led to the 
establishment of the "Communication Training Laboratory," an institution of the University of Macerata dedicated to innovation in teaching and learning.

Anna Arfelli Galli was awarded "professor emerita status" in 2003, but remained active in research and teaching. In 2004, she organized the Research Institute for Developmental Psychology and Educational Psychology at the University of Macerata, which she headed till 2012, and also remained active in doctoral studies in Educational Sciences.

Anna Arfelli's research work in all these fields has been marked by the primacy of respect for the other person ${ }^{1}$ and in its theoretical and methodological orientation explicitly and implicitly based on Gestalt psychology. Her understanding of Gestalt theory developed continuously in permanent dialogue and exchange, especially with Giuseppe Galli and her common circle of colleagues and friends, with her typical emphasis on interpersonal relationships and dialogicity and her openness for the integration of the thoughts of other compatible approaches in Gestalt theory.

A particularly impressive example of the achievements of Anna Arfelli Galli is her book "Gestaltpsychologie und Kinderforschung" ("Gestalt Psychology and Child Research"), which is currently available in German and Italian and will hopefully see an English translation soon. In this book, Anna Arfelli presents, for the first time, a detailed overview of the empirical research work of Gestalt theoretical orientation in child research from 1921 to 1975 , which up to now - because widely scattered and partly "lost" in long out-of-print publications - has hardly been perceived and used. Anna Arfelli Galli's book brings these works together in a way that makes them fruitful in a novel manner and shows their connection lines beyond the reporting period into contemporary research. By doing so, Anna Arfelli Galli did not simply lecture on the old, but created something new. It is to be hoped that this foundation, which she has prepared, will be effectively built up.

It is the characteristic of Anna Arfelli that she dedicated a substantial part of her remaining life after her her husband-and-colleague Giuseppe Galli's death on September 9, 2016, to the publication of an Italian edition of his last anthology, originally published in German": "La soggettività fenomenica. Integrazioni alla teoria della Gestalt." She was able to complete this book, the publication of which was so important to her, in the last weeks of her life, but unfortunately she did not live to see it published. On the occasion of the

\footnotetext{
${ }^{1}$ See: Nicolini, P., \& Pojaghi, B. (Eds.). (2006). Il rispetto dell'altro nella formazione e nell' insegnamento. Scritti in onore di Anna Arfelli. Macerata, Italy: EUM.

${ }^{2}$ Galli, G. (2016). Der Mensch als Mit-Mensch. Aufä̈tze von Giuseppe Galli zur Gestalttheorie in Forschung, Anwendung und Dialog. Herausgegeben und eingeleitet von Gerhard Stemberger. Wien, Austria: Krammer.
} 
book's presentation, a worthy commemoration for Anna Arfelli took place on September 20 at the headquarters of the publishing house EUM (Edizioni Università di Macerata); numerous colleagues, friends, and former students of Anna shared their memories of this remarkable person in the presence of her daughters and grandchildren.

A tremendous loss, a tremendous inspiration! You will be missed, Anna.

\section{Gerhard Stemberger, Vienna and Berlin}

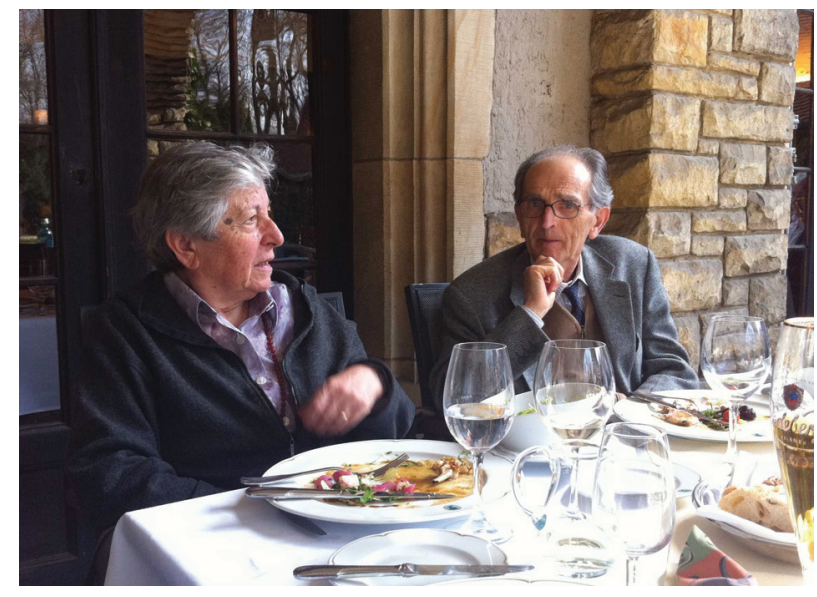

Anna Arfelli Galli and her husband Giuseppe Galli 2011 in Potsdam, Germany, participating in the $17^{\text {th }}$ International Scientific GTA-Conference.

\section{Selected book publications of Anna Arfelli Galli:}

1995. L'evoluzione del Sé. Teoria psicologica e prassi educativa. Assisi, Italy: Cittadella editrice.

1997 (Ed.). Didattica interattiva e formazione degli insegnanti. Bologna, Italy: Clueb.

1998. (Ed., with Michele Corsi): Riforma della scuola e formazione degli insegnanti in Italia. Pisa, Italy: Istituti

Editoriali e Poligrafici Internazionali.

2000. (Ed., with Anna Maria D’Emilo): Conoscersi per decidere. Uno studio sull'orientamento nella scuola di base.

Perugia, Italy: Morlacchi Editore.

2007. La rilevanza della Gestalttheorie per la ricerca psicologica. Macerata, Italy: Edizione Simple.

2013. Gestaltpsychologie und Kinderforschung. Wien, Austria: Krammer.

2013. La psicologia evolutiva nella scuola della Gestalt. Macerata, Italy: EUM.

2019. (Ed.): Giuseppe Galli - La soggettività fenomenica. Integrazioni alla teoria della Gestalt. Macerata, Italy: EUM. 